\title{
Melatonin in Semen Extender Improves Freezability in Mithun
}

\author{
P. Perumal*
}

ICAR-National Research Centre on Mithun, Medziphema, Nagaland (797 106), India

\author{
Corresponding Author \\ P. Perumal \\ e-mail: perumalponraj@gmail.com
}

\author{
Article History \\ Article ID: AR1941 \\ Received in $14^{\text {th }}$ December, 2018 \\ Received in revised form $14^{\text {th }}$ January, 2019 \\ Accepted in final form $16^{\text {th }}$ January, 2019
}

\begin{abstract}
Melatonin plays important roles in circadian clock regulation and seasonal reproduction in mammals. It is also a potential antioxidant and anti-apoptotic agent in semen preservation. Season/climatic factors/photoperiod and temperature humidity index is one of the most important factors, effect on the variation in semen quality parameters (SQPs) and fertility rate. The present study was conducted to assess the effect of melatonin (MT) on SQPs at different seasons of the year such as sperm motility, viability, total sperm abnormality, intactness of acrosome, functional plasma membrane and nuclear integrity in mithun. A total numbers of 80 ejaculates ( 20 ejaculates in each season) were collected twice per week from mithun bulls by transrectal massage method and semen sample was divided into six equal aliquots and diluted with the Tris egg yolk citrate glycerol extender (TEYCGE). Group 1: semen without additives (control), group 2 to 6: semen was diluted with 1, 2, 3, 4 and $5 \mathrm{mM}$ of melatonin, respectively. These SQPs were estimated in frozen thawed semen. Inclusion of melatonin into the diluent resulted in significantly $(p<0.05)$ decreased dead and abnormal spermatozoa percentage and acrosomal abnormalities whereas significant improvement was observed in the sperm motility, viability, plasma membrane and nuclear integrity in treatment as compared to control group at different seasons of the year. The present study result clearly indicated that melatonin protected the post thaw SQPs in different seasons and also semen quality varied from different seasons and was significantly higher in spring and lowest was in summer season.
\end{abstract}

Keywords: Melatonin, Mithun, semen, quality parameters, cryopreservation

\section{Introduction}

North-Eastern Hilly (NEH) region of Indian subcontinent has vast natural resources and great cultural diversity among the states of India. Among the livestock species of $\mathrm{NEH}$ region, mithun is a unique beautiful, magnificent domestic bovine species, used primarily for beef production and also is believed to be an economically important cattle species in NEH region. Mithun is not yet endangered, however affected from severe non-cyclical fluctuations of population on a national/ regional/international basis as per the livestock censuses of Government of India (Livestock Census, 2012). Different investigations on reproductive improvement revealed that mithun affected severely from intensive inbreeding depression and lack of suitable breeding bulls \& breeding management programme (Dhali et al., 2008). Mithuns are growing under free-range extensive system in field condition with available natural breeding as preferred practice with limitation of disease transmission control, inbreeding depression, poor body confirmation of bulls and therefore loss of productive and reproductive performances of future generations. The limitations of natural breeding could be easily controlled by following proper semen collection, cryopreservation and artificial insemination under field condition.

Various factors such as vaccination (Perumal et al., 2013a; Perumal et al., 2013b; Perumal, 2014a; Perumal, 2014b; Perumal, 2018a), seasons (Perumal et al., 2015; Rajoriya et al., 2016; Perumal et al., 2017a; Perumal et al., 2017b), pathological condition of reproductive system (Perumal, 2013; Perumal et al., 2013c; Perumal et al., 2016a), inclusion of additives (Perumal et a., 2012a; Perumal et al., 2012b), glycerol (Baruah et al., 2016) and hereditary and congenital causes (Perumal et al., 2012c) are affect the semen production and its quality. Season/climatic factors/photoperiod and temperature humidity index is one of the most important factors that have effect on the variation in semen quality parameters and fertility rate(Perumal et al., 2017a). Heat tolerance as well as disease resistance capability of the indigenous cattle (Bos indicus) is better than Bos taurus exotic cattle bulls, characterized by lower percentage total sperm abnormalities (Rajoriya et al., 2013). Almost in all the species higher semen production and its quality profiles were obtained during spring season. Humid hot season (higher temperature humidity index) is not suitable for highly motile as well as fertile semen production. In case of buffalo bulls, the 
animals perform better during winter as well as during spring seasons, whereas Bos indicus zebu bulls ejaculate semen with higher motility especially during spring as well as summer seasons (Rajoriya et al., 2013). Seasonal effect on freezability of buffalo bull semen clearly reported that the season has significant effect on post-thaw motility and values were being highest in semen samples collected and cryopreserved during winter and lowest was in summer season (Sagdeo et al., 1991).

Antioxidants are present in semen to protect the sperm against free radical (Perumal et al., 2013f; Perumal et al., 2014c). However, these antioxidants level are decreased during the process of extension and preservation process in liquid as well as in frozen state (Kumar et al., 2011; Perumal, 2017). Therefore, supplementation (Perumal et al., 2013f; Perumal et al., 2014c) or feeding of the natural/synthetic antioxidants (Jayaganthan et al., 2013; Jayaganthan et al., 2015) could able to reduce the deleterious effect of oxidative and cryo stress during the process of semen preservation (Perumal et al., 2011a; Perumal et al., 2011b). Melatonin is a natural indole derivative endogenous substance secreted rhythmically and released by the endocrine pineal gland in the brain and plays important roles in circadian clock regulation as well as seasonal reproduction in mammals (Reiter, 1991). Moreover, it was demonstrated that it has multiple actions on different physiological processes and also melatonin and its metabolites are the indirect powerful potential antioxidants and it is a powerful direct scavengers of free radicals (Reiter et al., 1998). Unlike the majority of other known free radical scavengers, melatonin is the multifunctional as well as universal antioxidants (Tomás-Zapico and Coto-Montes, 2005). It is an amphophilic compound as it is soluble both in water as well as in lipids as a hydrophilic and hydrophobic antioxidant. Further, it was reported that melatonin also stimulates the enzymes which are involved in metabolising free radicals and reactive oxygen species and preserves cell membrane fluidity suitable for higher fertility rate. As it was reported that melatonin has potent as twice as vitamin $E$ in scavenging the peroxyl radicals (Pieri et al., 1994) and also it is more effective in removing hydroxyl radicals than reduced glutathione or mannitol (Hardeland et al., 1993). It was also reported that melatonin minimizes or prevents the in vitro sperm capacitation and inhibit apoptotic like changes which indicates it has a direct action on spermatozoa. Inclusion of melatonin into the ram sperm (Ashrafi et al., 2011), boar sperm (Hyun-Yong et al., 2006), bull sperm (Ashrafi et al., 2013) and mithun (Perumal et al., 2013d) has been reported that it protected the sperm against the harmful effects of free radicals or ROS and improved the sperm motility, membrane integrity and ferility in the frozen state.

Further, available of literatures revealed scanty of information on effect of melatonin on the semen quality profiles during ultralow temperature cryopreservation of mithun semen at different seasons. Hence, the objective of this study was designed to assess the effect of this additive, melatonin on the post thaw SQPs in mithun at different seasons to pursuit future semen collection and preservation protocols.

\section{Materials and Methods}

\subsection{Experimental animals}

Eight apparently healthy adult mithun bulls of approximately 4 to 6 yr of age with good body condition (score 5-6) were selected from the herd of mithun derived from various hilly tracts of the NEH region of India especially Arunachal Pradesh, Nagaland, Manipur and Mizoram and maintained under uniform feeding, housing and lighting conditions in ICAR-National Research Centre on Mithun, Medziphema, Nagaland, India. Semen was collected from the animals through rectal massage method. Briefly, seminal vesicles were massaged centrally and backwardly for $5 \mathrm{~min}$ followed by the gentle milking of ampullae one by one for 3-5 min, which resulted into erection and ejaculation (Palmer et al., 2004). An assistant collected the semen as it was emitted from the preputial orifice into a plastic bag suspended in a thermos containing warm water at the bottom, resulting in a temperature of $35-38^{\circ} \mathrm{C}$ in the plastic bag. During collection, the initial transparent secretions were discarded and neat semen drops were collected in a graduated test tube with the help of a funnel.

\subsection{Semen collection and processing}

The collection seasons were divided into four based on the temperature humidity index viz. spring (February to April; THI: 63.51 \pm 1.85 ), summer (May to July; THI: 76.06 \pm 1.74 ), autumn (August to October; THI: 74.00 1 1.77) and winter

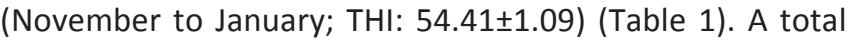
numbers of 40 ejaculates (10 ejaculates from each season)

\begin{tabular}{|c|c|c|c|c|c|c|c|}
\hline Seasons & $\begin{array}{c}\text { Sunshine } \\
\text { hours }\end{array}$ & $\begin{array}{l}\text { Dry bulb tem- } \\
\text { perature }\left({ }^{\circ} \mathrm{C}\right)\end{array}$ & $\begin{array}{c}\text { Wet Bulb tem- } \\
\text { perature }\left({ }^{\circ} \mathrm{C}\right)\end{array}$ & $\begin{array}{c}\text { Maximum tem- } \\
\text { perature }\left({ }^{\circ} \mathrm{C}\right)\end{array}$ & $\begin{array}{c}\text { Minimum tem- } \\
\text { perature }\left({ }^{\circ} \mathrm{C}\right)\end{array}$ & $\begin{array}{c}\text { Relative } \\
\text { Humidity (\%) }\end{array}$ & THI value \\
\hline Winter & $4.11 \pm 0.97^{a}$ & $10.62 \pm 0.90^{\mathrm{a}}$ & $8.57 \pm 0.92^{\mathrm{a}}$ & $24.62 \pm 0.84^{a}$ & $9.93 \pm 0.90^{\mathrm{a}}$ & $74.00 \pm 1.32^{\mathrm{a}}$ & $54.41 \pm 1.09^{a}$ \\
\hline Spring & $4.81 \pm 1.10^{\mathrm{ab}}$ & $17.09 \pm 1.63^{b}$ & $14.73 \pm 1.45^{b}$ & $29.84 \pm 1.57^{b}$ & $15.86 \pm 1.45^{b}$ & $76.33 \pm 2.01^{\mathrm{ab}}$ & $63.51 \pm 1.85^{b}$ \\
\hline Summer & $6.55 \pm 0.73^{b}$ & $25.44 \pm 1.19^{c}$ & $22.88 \pm 1.35^{c}$ & $32.48 \pm 0.70^{c}$ & $23.94 \pm 1.34^{c}$ & $80.00 \pm 1.90 b^{c}$ & $76.06 \pm 1.74^{c}$ \\
\hline Autumn & $6.32 \pm 0.85^{b}$ & $24.18 \pm 1.50^{c}$ & $22.21 \pm 1.46^{c}$ & $30.69 \pm 0.68 b^{c}$ & $23.34 \pm 1.48^{c}$ & $83.67 \pm 1.07^{c}$ & $74.00 \pm 1.77^{c}$ \\
\hline Overall & $5.45 \pm 1.14$ & $19.33 \pm 2.54$ & $17.10 \pm 2.51$ & $29.41 \pm 1.80$ & $18.27 \pm 2.49$ & $78.50 \pm 2.14$ & $66.99 \pm 3.06$ \\
\hline
\end{tabular}

Within column means with different superscripts $(a, b, c, d)$ differ significantly $(p<0.05)$ 
were collected from the mithun. Immediately after collection, the samples were kept in a water bath at $37{ }^{\circ} \mathrm{C}$ and evaluated for volume, colour, consistency, mass activity and $\mathrm{pH}$. After the preliminary evaluations, samples were subjected to the initial dilution with pre-warmed $\left(37^{\circ} \mathrm{C}\right)$ Tris egg yolk citrate glycerol extender (TEYCGE). The partially diluted samples were then brought to the laboratory in an insulated flask containing warm water $\left(37^{\circ} \mathrm{C}\right)$ for further processing.

Each ejaculate was split into six equal aliquots and diluted with the TEYCG extender with melatonin. Group 1: semen without additives (control), group 2 to group 6: semen with $1 \mathrm{mM}$, $2 \mathrm{mM}, 3 \mathrm{mM}, 4 \mathrm{mM}$ and $5 \mathrm{mM}$ of melatonin, respectively. However, $\mathrm{pH}$ of diluents was adjusted to be $6.8-7.0$ by using phosphate buffer solution. Diluted semen samples of control and treatment groups were cooled simultaneously from 37 to $5^{\circ} \mathrm{C}$ at a rate of $0.2-0.3^{\circ} \mathrm{C}$ per min in a cold cabinet (IMV, $L^{\prime}$ Aigle, France) and maintained at $5{ }^{\circ} \mathrm{C}$ for $2 \mathrm{~h}$. Polyvinyl chloride (PVC) straws (0.5 mL) (IMV, L'Aigle, France) were filled and maintained in a cold cabinet at $5{ }^{\circ} \mathrm{C}$ for $2.5 \mathrm{~h}$. Subsequently, these straws were wipe-cleaned, dried and spread over the freezing rack. The rack containing straws was kept in a biological programmable freezer for freezing (final temperature maintained at $-124{ }^{\circ} \mathrm{C}, 12 \mathrm{~min}$ ) followed by plunging of straws into the liquid nitrogen $\left(-196^{\circ} \mathrm{C}\right)$ and was stored therein. At the time of evaluation, the stored semen straws were taken out of the cryo-cans and thawed in water bath at $37^{\circ} \mathrm{C}$ for 30 s. The percentage of sperm motility, viability, total sperm abnormality (Tomar et al., 1997), acrosomal integrity (Watson 1975), plasma membrane integrity by hypo-osmotic swelling test (HOST) (Jeyendran et al., 1984) and nuclear integrity by Feulgen staining technique (Barth and Oko, 1989) were determined as per standard procedure.

\subsection{Sperm motility}

The forward progressive motility was recorded as percentage of progressively motile spermatozoa after the extension of semen. This was assessed by placing a drop of semen diluted (1:2-3) with Tris diluter on a clean, grease-free glass slide mounted on a stage maintained at $37^{\circ} \mathrm{C}$ and observed under high-power objective (20x) after covering with a cover slip. The semen sample was extended to such an extent that approximately 15-20 spermatozoa were visible under the visual field of microscope (Nikon, Eclipse 80i; magnification 200x). Individual progressive forward motility was observed as the percentage of the anterior progressive forward motility of spermatozoa (Salisbury et al., 1985).

\subsection{Viability and total sperm abnormality}

The per cent live spermatozoa was determined by adopting differential staining techniques using Eosin-Nigrosin staining as described by Lasley and Bogart (1944). Briefly, a drop of eosin $(5 \%)$ and nigrosin $(10 \%)$ solution was mixed on a glass slide. One drop of frozen-thawed semen was added to the stain on the slide and mixed. A thin smear was made and air- dried immediately by vigorous shaking. Live (unstained) and dead (stained, fully or partially) sperm cells were counted under 40x. These slides were examined for estimating the per cent of abnormal sperm, morphologically based on the observable abnormalities of head, neck, mid-piece and tail region of the spermatozoa (Lasley and Bogart, 1944).

\subsection{Acrosome integrity}

Acrosomal integrity of post-thawed spermatozoa was assessed using Giemsa stain (Watson, 1975). The slides were examined under oil immersion objective of the microscope to assess acrosome integrity. At least 200 spermatozoa were counted and categorized as having intact acrosome or abnormal or non-intact acrosome.

\subsection{Plasma membrane integrity}

For determining swelling pattern of spermatozoa in the hypoosmotic solution, solution-A ( $0.734 \mathrm{~g}$ sodium citrate) and solution $B$ ( $1.351 \mathrm{~g}$ fructose) were prepared in $100 \mathrm{ml}$ double distilled water. To prepare $1 \mathrm{ml}$ of hypo-osmotic solution of 150 mOsm l-1, $0.5 \mathrm{ml}^{\circ}$ of each solution A and B was taken in a clean, pre-warmed $\left(37^{\circ} \mathrm{C}\right)$ test tube. This solution is always prepared freshly before each test. The prepared hypo-osmotic solution was tested with advanced micro-Osmometer (Model No: $3 \mathrm{MO}$, USA) to ensure that osmolality of the solution remains $150 \mathrm{mOsm} \mathrm{I}^{-1}$. The hypo-osmotic swelling (HOS) response was assessed as described by Jeyendran et al. (1984). Pattern A: no swelling, no membrane reaction, pattern B: swelling of the tip of the tail, pattern C: different types of hairpin such as swelling pattern or swelling of the mid-piece, and pattern D: complete tail swelling. Spermatozoa displaying either pattern B, C or D were considered positive for HOST at post thawed stage.

\subsection{Nuclear integrity}

Feulgen reaction specifically and quantitatively stains the DNA in cellular material as described by Barth and Oko (1989). Treating sperm cells with mild solution of $\mathrm{HCL}$ hydrolyses the purine-deoxyribose linkages and exposes the free aldehydes group. The latter can react with Feulgen stain to form stable, coloured compound. The amount of stain colour developed is directly proportional to the amount of DNA present in the stained nuclei. For this assay, smear of sperm cells was prepared and fixed in $10 \%$ neutral buffered formal solution for $30 \mathrm{~min}$. After fixing, slides were washed in running water for $10 \mathrm{~min}$ and incubated for $30 \mathrm{~min}$ in $5 \mathrm{~N} \mathrm{HCL}$. Excess acid was removed by washing the slides twice in the running water for $5 \mathrm{~min}$ and then dipped in Schiff reagent (30 min, under dark condition). Excess reagent was removed by rinsing in sulphate water thrice at 2 min interval followed by washing in running water (10 $\mathrm{min}$ ). Stained slides were dried in air and examined using phase-contrast microscope (Nikon, Eclipse 80i; magnification 1000x). Total number (percentage) of normal and abnormal staining spermatozoa was determined by counting at least 200 cells per sample. Sperm abnormalities were classified into six categories: pyriform heads, giant- 
rolled-crested heads, pale staining cells, multiple vacuoles, single vacuoles and clumped nuclear material (Barth and Oko, 1989).

\subsection{Statistical analysis}

The statistical analysis of the data was performed as per standard procedures (Snedecor and Cochran, 1994). Analysis of variance (ANOVA) was performed using a generalized liner model (Statistical Analysis System for Windows, SAS Version 9.3; SAS Institute, Inc., Cary, NC, 2001) and treatment means were separated using Student-Newman-Keuls (SNK) multiple range test. Tables present the non-transformed data. The data used in the study were tested for normality before analysis using Shapiro-Wilk statistics. Means were analyzed by two way analysis of variance (ANOVA), followed by the Tukey's post hoc test to determine significant differences between the different seasons with treatment or without treatment on these sperm parameters using the SAS software /PC computer program. The per cent data were subjected to arcsine (angular) transformation before proceeding to general linear model. Differences with values of $p<0.05$ were considered to be statistically significant after arcsine transformation of percentage data.

\section{Results and Discussion}

Effects of melatonin on semen quality parameters such as total sperm motility (Table 2), viability (Table 3), total sperm abnormality (Table 4), intactness of acrosome (Table 5), functional plasma membrane integrity (Table 6) and nuclear integrity (Table 7$)$ in the frozen $\left(-196^{\circ} \mathrm{C}\right)$ thawed semen from different seasons were presented in tables. Results revealed that supplementation of melatonin into TEYCG diluent results decreased significantly $(p<0.05)$ the percentages of dead and abnormal spermatozoa as well as acrosomal abnormalities when samples were examined during different seasons as compared to the control group. Semen quality and effect of melatonin on semen quality parameters were

\begin{tabular}{|c|c|c|c|c|c|c|}
\hline \multirow[t]{2}{*}{ Seasons } & \multicolumn{6}{|c|}{ Experimental groups } \\
\hline & Control & MT $1 \mathrm{mM}$ & MT $2 \mathrm{mM}$ & MT $3 \mathrm{mM}$ & MT $4 \mathrm{mM}$ & MT $5 \mathrm{mM}$ \\
\hline Winter & $36.85 \pm 1.47^{\mathrm{CBC}}$ & $37.78 \pm 1.87^{\mathrm{bcBCD}}$ & $38.88 \pm 1.64^{\mathrm{bcCD}}$ & $40.41 \pm 1.58^{\mathrm{bD}}$ & $35.80 \pm 1.98 b^{c А B}$ & $33.82 \pm 1.97^{\mathrm{bA}}$ \\
\hline Spring & $38.38 \pm 1.29^{\mathrm{cA}}$ & $39.06 \pm 1.49^{\mathrm{cA}}$ & $41.62 \pm 2.19^{\mathrm{cB}}$ & $44.16 \pm 1.34^{c c}$ & $38.14 \pm 1.46^{\mathrm{cA}}$ & $37.03 \pm 1.47^{\mathrm{cA}}$ \\
\hline Summer & $30.39 \pm 1.82^{\mathrm{aAB}}$ & $32.92 \pm 1.61^{\mathrm{aAB}}$ & $33.12 \pm 2.10^{\mathrm{aB}}$ & $37.83 \pm 1.73^{\mathrm{ac}}$ & $32.16 \pm 1.53^{\mathrm{aAB}}$ & $30.17 \pm 1.53^{\mathrm{aA}}$ \\
\hline Autumn & $34.18 \pm 1.59 b^{A B C}$ & $35.40 \pm 1.93^{\mathrm{abBC}}$ & $36.40 \pm 1.69^{\mathrm{bCD}}$ & $39.18 \pm 1.38 a^{b D}$ & $32.97 \pm 2.18 a^{\mathrm{bAB}}$ & $31.14 \pm 2.14^{\mathrm{abA}}$ \\
\hline
\end{tabular}

Within columns means with different letters $(a, b, c, d)$ differ significantly $(p<0.05)$; Within rows means with different letters $(A, B, C, D)$ differ significantly $(p<0.05)$

Table 3: Mean ( \pm S.E.) post thaw viability of mithun sperm treated with melatonin at different seasons

\begin{tabular}{lcccccc}
\hline Seasons & \multicolumn{5}{c}{ Experimental groups } \\
\cline { 2 - 6 } & Control & MT 1 mM & MT 2 mM & MT 3 mM & MT 4 mM & MT 5 mM \\
\hline Winter & $42.29 \pm 1.86^{\mathrm{bAB}}$ & $44.28 \pm 1.61^{\mathrm{bBC}}$ & $46.18 \pm 1.29^{\mathrm{bC}}$ & $50.99 \pm 1.74^{\mathrm{bD}}$ & $43.82 \pm 1.81^{\mathrm{bcBC}}$ & $40.82 \pm 1.80^{\mathrm{bA}}$ \\
Spring & $45.33 \pm 1.56^{\mathrm{cBC}}$ & $47.11 \pm 1.13^{\mathrm{bC}}$ & $50.27 \pm 1.55^{\mathrm{cD}}$ & $56.24 \pm 1.30^{\mathrm{cE}}$ & $43.94 \pm 1.59^{\mathrm{cB}}$ & $41.32 \pm 1.70^{\mathrm{bA}}$ \\
Summer & $35.70 \pm 2.09^{\mathrm{aA}}$ & $38.10 \pm 2.13^{\mathrm{aAB}}$ & $41.12 \pm 2.30^{\mathrm{aB}}$ & $45.12 \pm 1.87^{\mathrm{ac}}$ & $38.37 \pm 2.23^{\mathrm{aAB}}$ & $36.41 \pm 2.23^{\mathrm{aA}}$ \\
Autumn & $40.34 \pm 1.39^{\mathrm{bB}}$ & $40.88 \pm 2.11^{\mathrm{aBC}}$ & $43.73 \pm 1.62^{\mathrm{abc}}$ & $50.15 \pm 1.85^{\mathrm{bD}}$ & $40.70 \pm 2.07^{\mathrm{abBC}}$ & $34.68 \pm 2.06^{\mathrm{aA}}$ \\
\hline
\end{tabular}

Within columns means with different letters $(a, b, c, d)$ differ significantly $(p<0.05)$; Within rows means with different letters $(A, B, C, D)$ differ significantly $(p<0.05)$

Table 4: Mean ( \pm S.E.) post thaw total sperm abnormality of mithun sperm treated with melatonin at different seasons

\begin{tabular}{lcccccc}
\hline \multirow{2}{*}{ Seasons } & \multicolumn{5}{c}{ Experimental groups } \\
\cline { 2 - 6 } & Control & MT 1 mM & MT 2 mM & MT 3 mM & MT 4 mM & MT 5 mM \\
\hline Winter & $21.00 \pm 0.63^{\mathrm{bE}}$ & $19.43 \pm 1.08^{\mathrm{bD}}$ & $18.27 \pm 0.80^{\mathrm{bC}}$ & $15.47 \pm 0.92^{\mathrm{bA}}$ & $17.01 \pm 0.77^{\mathrm{aB}}$ & $21.38 \pm 0.77^{\mathrm{bE}}$ \\
Spring & $19.21 \pm 1.10^{\mathrm{aE}}$ & $17.17 \pm 1.14^{\mathrm{aBC}}$ & $16.74 \pm 1.39^{\mathrm{aB}}$ & $14.28 \pm 0.87^{\mathrm{aA}}$ & $16.89 \pm 1.20^{\mathrm{aB}}$ & $18.64 \pm 1.12^{\mathrm{aCD}}$ \\
Summer & $26.63 \pm 1.08^{\mathrm{cC}}$ & $24.35 \pm 0.98^{\mathrm{cB}}$ & $21.28 \pm 1.04^{\mathrm{cA}}$ & $22.29 \pm 1.17^{\mathrm{dA}}$ & $25.83 \pm 1.19^{\mathrm{cC}}$ & $26.73 \pm 1.11^{\mathrm{cC}}$ \\
Autumn & $20.47 \pm 0.73^{\mathrm{bCD}}$ & $19.86 \pm 0.69^{\mathrm{bC}}$ & $17.65 \pm 0.84^{\mathrm{abB}}$ & $16.47 \pm 1.10^{\mathrm{cA}}$ & $18.29 \pm 1.02^{\mathrm{bB}}$ & $21.26 \pm 0.92^{\mathrm{bE}}$ \\
\hline
\end{tabular}

Within columns means with different letters $(a, b, c, d)$ differ significantly $(p<0.05)$; Within rows means with different letters $(\mathrm{A}, \mathrm{B}, \mathrm{C}, \mathrm{D})$ differ significantly $(p<0.05)$ 


\begin{tabular}{lcccccc}
\hline \multicolumn{6}{l}{ Table 5: Mean ( \pm S.E.) post thaw acrosomal integrity of mithun sperm treated with melatonin at different seasons } \\
\hline Seasons & \multicolumn{5}{c}{ Experimental groups } \\
\cline { 2 - 6 } & Control & MT 1 mM & MT 2 mM & MT 3 mM & MT 4 mM & MT 5 mM \\
\hline Winter & $46.30 \pm 1.28^{\mathrm{bA}}$ & $47.58 \pm 1.26^{\mathrm{bA}}$ & $50.72 \pm 1.77^{\mathrm{bB}}$ & $55.15 \pm 1.81^{\mathrm{bC}}$ & $48.39 \pm 1.41^{\mathrm{abAB}}$ & $47.34 \pm 1.46^{\mathrm{bCA}}$ \\
Spring & $48.72 \pm 1.65^{\mathrm{cA}}$ & $52.54 \pm 1.71^{\mathrm{cB}}$ & $54.40 \pm 1.28^{\mathrm{cB}}$ & $59.85 \pm 1.15^{\mathrm{cC}}$ & $52.63 \pm 1.85^{\mathrm{cB}}$ & $48.71 \pm 1.83^{\mathrm{cA}}$ \\
Summer & $40.38 \pm 1.57^{\mathrm{aA}}$ & $43.26 \pm 1.45^{\mathrm{aB}}$ & $47.13 \pm 1.66^{\mathrm{aC}}$ & $50.80 \pm 1.66^{\mathrm{aD}}$ & $46.50 \pm 1.44^{\mathrm{aC}}$ & $41.38 \pm 1.49^{\mathrm{aAB}}$ \\
Autumn & $46.35 \pm 1.57^{\mathrm{bA}}$ & $49.11 \pm 1.01^{\mathrm{bB}}$ & $51.22 \pm 1.19^{\mathrm{bC}}$ & $54.36 \pm 1.59^{\mathrm{bD}}$ & $50.25 \pm 1.50^{\mathrm{bBC}}$ & $45.28 \pm 1.54^{\mathrm{bA}}$ \\
\hline
\end{tabular}

Within columns means with different letters $(a, b, c, d)$ differ significantly $(p<0.05)$; Within rows means with different letters $(A, B, C, D)$ differ significantly $(p<0.05)$

Table 6: Mean ( \pm S.E.) post thaw plasma membrane integrity of mithun sperm treated with melatonin at different seasons

\begin{tabular}{lcccccc}
\hline Seasons & \multicolumn{5}{c}{ Experimental groups } \\
\cline { 2 - 7 } & Control & MT 1 mM & MT 2 mM & MT 3 mM & MT 4 mM & MT 5 mM \\
\hline Winter & $42.27 \pm 1.65^{\mathrm{bA}}$ & $44.42 \pm 1.78^{\mathrm{bAB}}$ & $49.24 \pm 1.51^{\mathrm{bC}}$ & $53.06 \pm 1.61^{\mathrm{bD}}$ & $45.99 \pm 1.77^{\mathrm{bBC}}$ & $42.25 \pm 1.76^{\mathrm{bA}}$ \\
Spring & $47.42 \pm 1.34^{\mathrm{dB}}$ & $48.10 \pm 1.29^{\mathrm{cB}}$ & $51.92 \pm 1.84^{\mathrm{cD}}$ & $60.69 \pm 1.62^{\mathrm{CE}}$ & $45.61 \pm 1.48^{\mathrm{bB}}$ & $43.01 \pm 1.55^{\mathrm{bA}}$ \\
Summer & $36.20 \pm 1.80^{\mathrm{aA}}$ & $41.30 \pm 1.96^{\mathrm{aBC}}$ & $42.96 \pm 1.71^{\mathrm{aC}}$ & $48.27 \pm 1.60^{\mathrm{aD}}$ & $40.10 \pm 2.19^{\mathrm{aBC}}$ & $38.12 \pm 2.19^{\mathrm{aAB}}$ \\
Autumn & $44.43 \pm 1.29^{\mathrm{cB}}$ & $44.85 \pm 2.04^{\mathrm{bBC}}$ & $48.22 \pm 1.97^{\mathrm{bC}}$ & $52.24 \pm 1.71^{\mathrm{bD}}$ & $44.10 \pm 1.62^{\mathrm{bAB}}$ & $41.14 \pm 1.59^{\mathrm{bA}}$ \\
\hline
\end{tabular}

Within columns means with different letters $(a, b, c, d)$ differ significantly $(p<0.05)$; Within rows means with different letters $(A, B, C, D)$ differ significantly $(p<0.05)$

\begin{tabular}{lcccccc}
\hline \multicolumn{5}{l}{ Table 7: Mean ( \pm S.E.) post thaw nuclear integrity of mithun sperm treated with melatonin at different seasons } \\
\hline \multirow{5}{*}{ Seasons } & \multicolumn{5}{c}{ Experimental groups } \\
\cline { 2 - 6 } & Control & MT 1 mM & MT 2 mM & MT 3 mM & MT 4 mM & MT 5 mM \\
\hline Winter & $51.66 \pm 1.61^{\mathrm{bAB}}$ & $54.14 \pm 1.76^{\mathrm{bcBC}}$ & $57.00 \pm 1.37^{\mathrm{bCCD}}$ & $59.25 \pm 1.60^{\mathrm{bD}}$ & $53.11 \pm 2.05^{\mathrm{bAB}}$ & $50.23 \pm 2.05^{\mathrm{bA}}$ \\
Spring & $52.28 \pm 1.66^{\mathrm{bA}}$ & $56.31 \pm 1.53^{\mathrm{cBC}}$ & $58.87 \pm 1.91^{\mathrm{cC}}$ & $64.09 \pm 1.35^{\mathrm{cD}}$ & $54.30 \pm 1.73^{\mathrm{bAB}}$ & $52.33 \pm 1.70^{\mathrm{bA}}$ \\
Summer & $43.19 \pm 1.73^{\mathrm{aA}}$ & $47.17 \pm 2.10^{\mathrm{aB}}$ & $49.39 \pm 1.92^{\mathrm{aB}}$ & $53.42 \pm 2.00^{\mathrm{aC}}$ & $49.26 \pm 1.82^{\mathrm{aB}}$ & $46.73 \pm 1.70^{\mathrm{aB}}$ \\
Autumn & $50.22 \pm 1.73^{\mathrm{bA}}$ & $53.58 \pm 1.51^{\mathrm{bB}}$ & $55.07 \pm 1.55^{\mathrm{bB}}$ & $58.10 \pm 1.45^{\mathrm{bC}}$ & $52.00 \pm 1.79^{\mathrm{abA}}$ & $50.22 \pm 1.79^{\mathrm{bA}}$ \\
\hline
\end{tabular}

Within columns means with different letters $(a, b, c, d)$ differ significantly $(p<0.05)$; Within rows means with different letters $(A, B, C, D)$ differ significantly $(p<0.05)$

significantly $(p<0.05)$ differed between the seasons and were significantly higher in spring season and lowest was in summer season. Mean total sperm abnormalities were $19.21 \pm 1.10,17.17 \pm 1.14,16.74 \pm 1.39,14.28 \pm 0.87,16.89 \pm 1.20$ and $18.64 \pm 1.12$, respectively for control, $1 \mathrm{mM}, 2 \mathrm{mM}, 3$ $\mathrm{mM}, 4 \mathrm{mM}$ and $5 \mathrm{mM}$ of melatonin treated mithun semen in spring season. Additionally, melatonin at $1 \mathrm{mM}, 2 \mathrm{mM}, 4$ $\mathrm{mM}$ and $5 \mathrm{mM}$ were significantly inferior to melatonin at 3 $\mathrm{mM}$ treatments for these semen quality attributes and there was a significant $(p<0.05)$ difference between melatonin at $1 \mathrm{mM}, 2 \mathrm{mM}, 4 \mathrm{mM}, 5 \mathrm{nM}$ and $3 \mathrm{mM}(3 \mathrm{mM}$ vs $1,2,4,5$ $\mathrm{mM}$ ) for these response at different seasons. It was obvious from the present data of the experiment that inclusion of melatonin especially at $3 \mathrm{mM}$ to the semen diluent resulted in significant improvement in SQPs and reduction of sperm nuclear, acrosomal and morphological abnormalities in mithun sperm stored in cryopreserved at $-196^{\circ} \mathrm{C}$ in different seasons. Moreover, semen from spring season has higher freezability and melatonin inclusion during spring season has significantly higher semen quality and freezability whereas significantly lower semen quality and freezability was observed in summer season.

Results revealed in the present study that inclusion of melatonin in the semen extender, mixed with semen which was collected at different seasons has improved the SQPs and was higher in spring than summer season. Thus melatonin protects the structural stability and function ability of the spermatozoa efficiently at different seasons. Semen quality was differed between the seasons, higher was in spring followed by autumn, winter and lower was in summer season. Thus, melatonin has enhanced the semen quality by cryopreserving efficiently during artificial insemination procedure in mithun species at different seasons. There were scanty reports available on effect of inclusion of melatonin on SQPs in mithun at different seasons at ultra-low temperature $\left(-196^{\circ} \mathrm{C}\right)$ and this is the first report of the effect of melatonin on SQPs in cryopreserved mithun semen, collected at different 
seasons to the best of our knowledge. However, various authors reported that melatonin has significant beneficial effects on cryopreservation of mammalian sperm and improves the SQPs of spermatozoa (Ashrafi et al., 2011; HyunYong et al., 2006; Ashrafi et al., 2013). Melatonin inclusion on these SQPS revealed significant difference between the treatment groups in different seasons. The beneficial effects of melatonin in semen cryopreservation are due to it is a very potent antioxidant (Ashrafi et al., 2011; Hyun-Yong et al., 2006; Ashrafi et al., 2013). Season is one of the essential criteria that have altered the variation in SQPs and fertility. Semen quality parameters are significantly affected by seasons. Heat tolerance as well as disease resistance capacity of indigenous cattle (Bos indicus) is significantly higher than exotic (Bos taurus) bulls characterized by lower percentage of total sperm abnormalities (Rajoriya et al., 2013).

Mammalian sperm membrane made up of high polyunsatured fatty acids and it renders the sperm very susceptible to affected with lipid peroxidation, which happens as a result of the peroxidation of the membrane lipids by partially reduced oxygen molecules such as hydrogen peroxide, superoxide and hydroxyl radicals (Dandekar et al., 2002; Perumal et al., 2016b). Lipid peroxidation of the sperm membrane finally inturn to impairment of function of the sperm due to higher attacks by free radical or ROS causes alteration of total sperm motility and membrane integrity and damage to sperm DNA and infertility through oxidative stress and production of cytotoxic aldehydes (Perumal et al., 2011a). Besides, the antioxidant system of seminal plasma as well as spermatozoa is compromised during semen dilution and processing (Alvarez and Storey, 1992). The antioxidant concentration decreased during the preservation process by dilution of semen with extender and excessive generation of free radical or ROS molecules (Kumar et al., 2011). Natural as well as synthetic antioxidant systems have been explained as a defense functioning mechanism against lipid peroxidation in semen (Kumar et al., 2011). Therefore, supplementation of exogenous antioxidants with naturally available could reduce the impact of oxidative stress during the sperm storage process and thus improve the quality of cryopreserved semen (Ashrafi et al., 2011; Perumal et al., 2013e). Seasons are also majorly influenced on the LPO production and antioxidant concentration as higher level of antioxidant was reported in winter as compared to summer season and higher LPO in summer season than in winter season in semen of Tharparkar bull (Rajoriya et al., 2013).

The summer season causes thermal and hot stress to the animal which also affect the Leydig cell function as chronic heat treatment has to reduce testosterone production and functions of accessory sex glands especially epididymis as well as seminal vesicles because as these antioxidants are arrived from epididymis mainly cauda epididymis (Fouchecourt et al., 2000) and seminal vesicle (Tramer et al., 1998) into the semen stream because the epididymis, accessory sex glands are thermo sensitive and androgen dependent (Saeed et al., 1994). Therefore the production of antioxidants was lower and LPO production was higher in summer than in spring or autumn or winter season in mithun.

The results of the present study showed that inclusion of melatonin at $3 \mathrm{mM}$ improved the keeping quality of mithun semen which cryopreserved at $-196{ }^{\circ} \mathrm{C}$ in different seasons and was higher in spring season. But the sperm motility was declined in summer season. Similar reports were observed in indigenous Tharparkar cattle (Rajoriya et al., 2013) that winter season favours more sperm motility than summer season. Similar report was also observed in another mountain animal yak as sperm from autumn season was significantly better SQPs than summer season (Sarkar et al., 2009). The motility of sperm cell develops during their passage through the epididymis. Anaphylactic stress caused by summer heat stress, as depicted by the significant rise in body as well as testes temperature causes derangement in epididymal functions and spermatogenesis which could lead to summer stressmediated decreased sperm motility and with similar feature of testicular hypoplasia and degeneration (Arthur et al., 1989). Higher temperature could give rise to secondary sperm abnormalities as well with increase in sperm tail and mid-piece abnormalities as reported in testicular degeneration or partial hypoplasia of testes (Sullivan, 1978).

Similarly, reduced rate of the sperm motility percentage was significantly higher in semen samples treated with 4 or $5 \mathrm{mM}$ melatonin or without melatonin (control). Whereas inclusion of melatonin at $3 \mathrm{mM}$ causes the motility and viability parameters were increased as compared to control group (Succu et al., 2011). The differential effects of the different concentration of melatonin might be explained according to the report of Ashrafi et al. (2011) reported that the excessive amount of antioxidants than threshold causes alteration of the osmotic pressure or physiological changes of the extender and high fluidity of plasma membrane above the desired point, making the sperm more susceptible to damages on acrosome which may be harmful to spermatozoa that leads to decreased the spermatozoa performance after cryopreservation at ultralow temperature. In addition to this, the concentration of antioxidants included to extender should be considered since higher dosage of antioxidants may be harmful to spermatozoa due to the change in physiological condition of semen extender. In mithun, survival of spermatozoa will increase when the concentration of antioxidant included to extender increases. However, the antioxidant concentration higher than required amount was toxic to spermatozoa (Perumal et al., 2015). The over expression of melatonin may reflect a defect in the development or maturation of spermatozoa as well as sperm cellular damage, resulting in decreased sperm fertilization potential (Ashrafi et al., 2013). Similarly, in the present study, increasing dosage of melatonin, at $4 \mathrm{mM}$ or $5 \mathrm{mM}$ affected the seminal parameters in mithun semen TEYCG extender. At the same time, less concentration also 
affected the semen quality parameters. However as per the concentration, the SQPs were increased from control to $3 \mathrm{mM}$ then decreased to $5 \mathrm{mM}$. Differences in preservation protocols and extender formulations among laboratories, the time of addition/exposure of sperm with antioxidant, concentration of antioxidants and between species may explain, at least in part, this variability. The improvement of semen quality due to addition of exogenous melatonin recorded in the present study was previously reported in the form of motility and intact acrosomal membrane in ram sperm (Ashrafi et al., 2011), boar sperm (Hyun-Yong et al., 2006), bull sperm (Ashrafi et al., 2013) and mithun (Perumal et al., 2013d). Moreover, the addition of exogenous melatonin was significantly improving the percentages of DNA morphology, sperm viability and intact plasma membrane (swelling tails) especially at a level of $3 \mathrm{mM}$ of melatonin. The highest percentages of acrosomal membranes and intact plasma which were observed in the present study due to melatonin at $3 \mathrm{mM}$ may be the reason for higher motility in these samples (Ashrafi et al., 2013). Mitochondria in sperm cells encase the axosome, connect with dense fibres in the middle pieces and produce adenosine triphosphate (ATP). It has been reported (Aitken and Clarkson, 1987) that the axoneme and mitochondria in sperms may be damaged by a high level of ROS. Studies have shown that melatonin can stabilise and protect the mitochondria through several different mechanisms (Lopez et al., 2009).

Melatonin helps to maintain the integrity of normal acrosome and stabilizes the plasmalemma of spermatozoa causes increase of motility (Sonmez et al., 2007). Melatonin, in sperm cells, reacts with many free radicals directly for protecting mammalian cells against oxidative stress or ROS and hence maintaining the total sperm motility (Ashrafi et al., 2013). Therefore, in this study, attempts to improve the motility and viability of the sperm cells by incorporating melatonin in cryopreservation (Ashrafi et al., 2011) and already frozen semen form have been investigated in other species (Ashrafi et al., 2013). Similar result was reported in Tharparkar bulls as semen ejaculates from winter season have significantly higher total sperm acrosomal integrity than ejaculates collected from summer season (Rajoriya et al., 2013).

Since, functional plasma membrane integrity indicates the biochemical integrity of sperm plasma membrane and it is involved in the process of capacitation, acrosome reaction and ultimately binding of spermatozoa to the oocyte for fertilization (Argov et al., 2007). So, this test is able to assess the fertilizing ability of spermatozoa and the ultimate target of which is to reduce the incidence of repeat breeding problem in mithun. Perumal (2018b) observed that decrease in HOST reacting spermatozoa following scrotal insulation in mithun due to increase of testicular temperature and body temperature as in summer hot stress. Similarly, in a study on bulls, HOS test reacting spermatozoa were reduced after heat treatment (Sivaramalingam, 1994) similar to summer season. Thus it can be proposed that summer heat stress affects the
HOS percentage by affecting the biochemical integrity of the sperm plasma membrane. Similar report was observed in indigenous (Bos indicus) cattle (Rajoriya et al., 2013), buffaloes (Sagdeo et al., 1991), sheep (Colas 1980), goat (Zarazaga et al., 2009) and horse (Pickett et al., 1975) as season has significance influence on sperm acrosomal integrity.

In general, sperm morphology usually returns to normal value within approximately 8 weeks of the thermal insult (Kastelic et al., 1996). However, a prolonged and (or) severe increase in testicular temperature will increase the interval for recovery in summer season. It appears that the decrease in semen quality associated with increased testicular temperature is ultimately related to the severity and the duration of the increased testicular temperature.

$A$ recent study report indicated that semen quality is deteriorated (Aitken et al., 2010) by which DNA damage is induced in the male gamete by oxidative stress and spermatozoa are particularly vulnerable to this because they generate ROS and are rich in targets for oxidative attack. The author also draws attention to the fact that, because spermatozoa are transcriptionally inactive and have little cytoplasm, they are deficient in both antioxidants and DNA-repair systems. Oxidative stresses may be a cause of male infertility and contribute to DNA fragmentation in spermatozoa (Perumal et al., 2011b). There are few studies on the effects of antioxidant inclusion to the extenders during cooling and/or freezing mammalian spermatozoa (Ashrafi et al., 2013). In mithun semen, ROS are generated mainly by damaged and abnormal spermatozoa and by contaminating leukocytes. ROS damage the cells by changes to lipids, proteins and DNA. Spermatozoa are potentially susceptible to peroxidative damage caused by ROS excess due to high amounts of polyunsaturated fatty acids in membrane phospholipids of sperm and to sparse cytoplasm. In the present study, inclusion of melatonin has decreased the DNA integrity /nuclear integrity especially at $3 \mathrm{mM}$ in mithun semen preserved at $-196^{\circ} \mathrm{C}$ in different seasons. It is similar to reports of Succu et al. (2011) that the inclusion of melatonin preserved DNA integrity in cryopreserved ram spermatozoa.

Moreover, it maintains plasma and mitochondrial membrane integrity and cytoskeleton structure of flagella of sperm as cell protecting effects. Melatonin has also protects and stimulates the activities of antioxidant enzymes (Karbownik and Reiter, 2000), which helps to maintain membrane transportation (Alvarez and Storey, 1992) and fertility of the spermatozoa. It results indirectly decrease the number of free radicals, ROS and also may increase the production of molecules protecting the sperm cells against oxidative stress. Indeed, melatonin was shown to be twice as potent as vitamin $\mathrm{E}$ in removing peroxyl radicals (Pieri et al., 1994) and it is more effective in scavenging the hydroxyl radicals than reduced glutathione and mannitol (Hardeland et al., 1993).

Melatonin is produced and secreted during the night (dark). 
As days become shorter, the exposure to melatonin increases; this hormone, through a complex action on the hypothalamuspituitary-gonads axis, exerts a stimulating effect on $\mathrm{GnRH}$ secretion by the hypothalamus and modulating gonadotropin and testosterone production (Gavella and Lipovac, 2000) in short-day breeders. In the present study, semen production and semen quality were significantly higher in spring and winter seasons, the seasons have short day light. This indicates that during this short day season, there was more secretion of melatonin in mithun and protected the semen quality parameters along with stimulation of hypothalamus to secrete more GnRH followed by high semen production. Moreover, there may be high variation in melatonin secretion and concentration throughout the year in mithun seminal plasma that could partly explain the differences in sperm quality and fertility observed between the breeding and non-breeding seasons (Ashrafi et al., 2013) in mithun species. Similarly, in mithun cows, short day may induce secretion of melatonin, stimulation of $\mathrm{GnRH}$ followed by expression of heat, breeding, conception and calving. But in the present study, we didn't measure the melatonin and other reproductive hormones concentration in different season in both male and female animal.

\section{Conclusion}

Improvements in SQPS may be due to prevention of excessive generation of ROS by antioxidant property of melatonin indicates that the melatonin protects in dose dependent manner. Thus it protected the spermatozoa during preservation and enhancing fertility at $3 \mathrm{mM}$. Further, semen production and melatonin effect on SQPs were higher in spring than in summer season. Concluded that semen collection and preservation should be conducted from winter to spring season (November to April) and $3 \mathrm{mM}$ melatonin is more suitable for semen cryopreservation.

\section{Acknowledgement}

This research work was supported by a grant from the Department of Biotechnology, Government of India, New Delhi, India for the project entitled "Evaluation of melatonin as fertility marker in Mithun (Bos frontalis) bulls: Effect on circadian rhythm and seasonal variation in SQPs" (Project No. BT/PR9590/AAQ/1/562/2013 dated 05.12.2014).

\section{References}

Aitken, R.J., Clarkson, J.S., 1987. Cellular basis of defective sperm function and its association with the genesis of reactive oxygen species by human spermatozoa. Journal of Reproduction and Fertility 81(2), 459-469.

Aitken, R.J., De Luliis, G.N., Finnie, J.M., Hedges, A., McLachlan, R., 2010. Analysis of the relationships between oxidative stress, DNA damage and sperm vitality in a patient population: development of diagnostic criteria. Human Reproduction 25(10), 2415-2426.

Alvarez, J.G., Storey, B.T., 1992. Evidence for increased lipid peroxidative damage and loss of superoxide dismutase activity as a model of sub lethal cryo damage to human sperm during cryopreservation. Journal of Andrology 13, 232-241.

Argov, N., Sklan, D., Zeron, Y., Roth, Z., 2007. Association between seasonal changes in fatty-acid composition, expression of VLDL receptor and bovine sperm quality. Theriogenology 67, 878-885.

Arthur, G.H., Noakes, D.E., Pearson, H., 1989. Veterinary Reproduction and Obstetrics.6th edn. London. Bailliere Tindal, 509-584.

Ashrafi, I., Kohram, H., Ardabili, F.F., 2013. Antioxidative effects of melatonin on kinetics, microscopic and oxidative parameters of cryopreserved bull spermatozoa. Animal Reproduction Science 139(1-4), 25-30.

Ashrafi, I., Kohram, H., Naijian, H., Bahreini, M., Poorhamdollah, M., 2011. Protective effect of melatonin on sperm motility parameters on liquid storage of ram semen at 5 ${ }^{\circ} \mathrm{C}$. African Journal of Biotechnology 10(34), 6670-6674.

Baruah, K.K., Mondal, M., Dhali, A., Bora, B., Mech, A., Baruah, A., Perumal, P., Das, K.C., 2016. Research on freezability of spermatozoa by use of various concentrations of glycerol in mithun (Bos frontalis) semen cryopreservation. International Journal of Bioresource and Stress Management 7(5), 1173-1176.

Barth, A.D., Oko, R.J., 1989. Preparation of semen for morphological examination in Abnormal morphology of bovine spermatozoa. lowa State University Press, Ames, IA, 8-18.

Colas, G., 1980. Seasonal variations of the quality of sperm in the lle-de-France ram. I. Study of the cellular morphology and "massal" motility. Reproduction, Nutrition and Development 20, 1789-1799.

Dandekar, P., Nadkarni, G.D., Kulkarni, V.S., Punekar, S., 2002. Lipid peroxidation and antioxidant enzymes in male infertility. Journal of Postgraduate Medicine 48, 186-189.

Dhali, A., Mech, A., Prakash, B., Mondal, M., Mukherjee, A., Mukherjee, S., Rajkhowa, S., Baruah, K.K., Das, K.C., 2008. Breeding Management (cited in: Mithun: A gifted bio- resource of the north eastern hills), ICAR-NRC on Mithun, Nagaland, India, 32-24.

Fouchecourt, S., Metayer, S., Locatelli, A., Dacheux, F., Dacheux, J.L., 2000. Stallion epididymal fluid proteome: qualitative and quantitative characterization; secretion and dynamic changes of major proteins. Biology of Reproduction 62, 1790-1803.

Gavella, M., Lipovac, V., 2000.Antioxidative effect of melatonin on human spermatozoa. Archives of Andrology 44(1), 23-27.

Hardeland, R., Reiter, R.J., Poeggeler, B., Tan, D.X., 1993. The significance of the metabolism of the neurohormone melatonin: Antioxidative protection and formation of bioactive substances. Neuroscience and Biobehavioral Reviews 17(3), 347-357.

Hyun-Yong, J., Sung-Gon, K., Jong-Taek, K., Choon-Keun, P., 
Hee-Tae, C., Hak-Kyu, L., Boo-Keun, Y., 2006. Effects of antioxidants on sperm motility during in vitro storage of boar semen. Korean Journal of Gerontology 16(6), 47-51.

Jayaganthan, P., Perumal, P., Balamurugan, T.C., Verma, R.P., Singh, L.P., Pattanaik, A.K., Kataria, M., 2013. Effects of Tinospora cordifolia supplementation on semen quality and hormonal profile of ram. Animal Reproduction Science 140(1), 47-53.

Jayaganthan, P., Perumal, P., Balamurugan, T.C., Verma, R.P., 2015. Effect of Tinospora cordifolia supplementation on sexual behaviuor and semen production of rams. Indian Journal of Animal Research 49(1), 135-137.

Jeyendran, R.S., Vander Ven, H.H., Parez-Pelaez, M., Crabo, B.G., Zaneweld, L.J.D., 1984. Development of an assay to assess the functional integrity of the human membrane and its relationship to other semen characteristics. Journal of Reproduction and Fertility 70, 219-28.

Karbownik, M., Reiter, R.J., 2000.Antioxidative effects of melatonin in protection against cellular damage caused by ionizing radiation. Proceedings of the Society for Experimental Biology and Medicine 225(1), 9-22.

Kastelic, J.P., Cook, R.B., Coulter, G.H., Saacke, R.G., 1996. Insulating the scrotal neck affects semen quality and scrotal/testicular temperatures in the bull. Theriogenology 45, 935-942.

Kumar, R., Jagan Mohanarao, G., Arvind, R., Atreja, S.K., 2011. Freeze-thaw induced genotoxicity in buffalo (Bubalus bubalis) spermatozoa in relation to total antioxidant status. Molecular Biology Report 38(3), 1499-1506.

Lasley, J.F., Bogart, R., 1944. A comparative study of epididymal and ejaculated spermatozoa of boar. Journal of Animal Science 3, 360-370.

Livestock Census of India (19 $9^{\text {th }}$., 2012. All India Report. Ministry of Agriculture Department of Animal Husbandry, Dairying and Fisheries, Krishi Bhawan, New Delhi, India, 2012.

Lopez, A., Garcia, J.A., Escames, G., Venegas, C., Ortiz, F., Lopez, L.C., Acuna- Castroviejo, D., 2009. Melatonin protects the mitochondria from oxidative damage reducing oxygen consumption, membrane potential, and superoxide anion production. Journal of Pineal Research 46(2), 188-198.

Palmer, C., Amundson, S., Brito, L., Waldner, C., Barth, A., 2004. Use of oxytocin and cloprostenol to facilitate semen collection by electro-ejaculation or transrectal massage in bulls. Animal Reproduction Science 80, 213-223.

Perumal, P., Selvaraju, S., Selvakumar, S., Barik, A.K., Mohanty, D.N., Das, R.K., Srinibas Das, Mishra, P.C., 2011a.Effect of pre-freeze addition of cysteine hydrochloride and reduced glutathione in semen of crossbred Jersey bulls on sperm parameters and conception rates. Reproduction in Domestic Animals 46(4), 636-641.

Perumal, P., Selvaraju, S., Barik, A.K., Mohanty, D.N., Das, S., Mishra, P.C., 2011b. Role of reduced glutathione in improving post-thaw seminal parameters in poor freezable Jersey crossbred bull semen. Indian Journal of Animal Sciences 81, 807-810.

Perumal, P., Selvaraju, S., Barik, A.K., Mohanty, D.N., Das, S., Mishra, P.C., Veeraselvam, M., 2012a. Reduced glutathione and cysteine hydrochloride on sperm motility and velocity parameters of poor crossbred bull semen. International Journal of Bio-Resource and Stress Management 3(2), 145-151.

Perumal, P., Selvaraju, S., Barik, A.K., Mohanty, D.N., Das, S., Mishra, P.C., Veeraselvam, M., 2012b. Cysteine hydrochloride on post-thawed seminal characters of Jersey crossbred bull. International Journal of BioResource and Stress Management 3(2), 232-235.

Perumal, P., Srivastava, N., Srivastava, S.K., Chamuah, J.K., Veeraselvam, M., 2012c. Hereditary and congenital causes of infertility in buffalo (Bubalus bubalis) bulls. International Journal of Bio-Resource and Stress Management 3(4), 472-480.

Perumal, P., 2013. Effect of unilateral cryptorchidism on seminal parameters of mithun (Bos frontalis). Indian Veterinary Journal 91(9), 43-46.

Perumal, P., Khate, K., Rajkhowa, C., 2013a. Effect of foot and mouth disease vaccination on seminal and biochemical profiles of mithun (Bos frontalis) semen. Asian Pacific Journal of Reproduction 2(3), 209-214.

Perumal, P., Vupru, K., Khate, K., Veeraselvam, M., Verma, A.K., 2013b.Effect of foot and mouth disease vaccination on the semen quality of mithun (Bos frontalis). Advances in Animal and Veterinary Sciences 1(5), 151-156.

Perumal, P., Vupru, K., Khate, K., Veeraselvam, M., Verma, A.K., Nahak, A.K., Rajkhowa, C., 2013c. Spontaneous erection and masturbation in mithun (Bos frontalis) bulls. International Journal of Bio-Resource and Stress Management 4(4), 645-647.

Perumal, P., Vupru, K., Khate, K., 2013d. Effect of addition of melatonin on the liquid storage $\left(5^{\circ} \mathrm{C}\right.$ ) of mithun (Bos frontalis) semen. International Journal of Zoology 2013, 10 Pages, Article id. 642632.

Perumal, P., Vupru, K., Rajkhowa, C., 2013e. Effect of addition of taurine on the liquid storage $\left(5^{\circ} \mathrm{C}\right.$ ) of mithun (Bos frontalis) semen. Veterinary Medicine International 2013, 7 Pages, Article Id. 165348.

Perumal, P., Chamuah, J.K., Rajkhowa, C., 2013f. Effect of catalase on the liquid storage $\left(5^{\circ} \mathrm{C}\right.$ ) of mithun (Bos frontalis) semen. Asian Pacific Journal of Reproduction 2(3), 209-214.

Perumal, P., 2014a. Studies on effect of low density lipoprotein on freezability and fertilizing ability of spermatozoa in mithun (Bos frontalis) bulls. Ph.D. Thesis submitted to ICAR-Indian Veterinary Research Institute, Deemed University, Izatnagar, Bareilly, Uttar Pradesh, India.

Perumal, P., 2014b. Effect of foot and mouth disease vaccination on semen production in mithun (Bos frontalis). Journal of Research 1, 935.

Perumal, P., 2014c. Effect of superoxide dismutase on the 
liquid storage $\left(5^{\circ} \mathrm{C}\right)$ of mithun (Bos frontalis) semen. Journal of Animals 2014, 1-9, Article ID 821954.

Perumal, P., Chamuah, J.K., Nahak, A.K., Rajkhowa, C., 2015. Effect of melatonin on the liquid storage $\left(5^{\circ} \mathrm{C}\right)$ of semen with retrospective study of calving rate at different season in mithun (Bos frontalis). Asian Pacific Journal of Reproduction 4(1), 1-12.

Perumal, P., Chang, S., Sangma, C.T.R., Khate, K., Saminathan, M., 2016a.Unilateral cryptorchidism on mobility and velocity parameters in mithun sperm. Journal of Experimental Biology and Agricultural Sciences 4(spl-3), S116-S122.

Perumal, P., Barik, A.K., Mohanty, D.N., Das, S., Mishra, P.C., Chang, S., 2016b. Comparison of Semen Characteristics of Good and Poor Freezable Jersey Crossbred Bulls. International Journal of Bio-Resource and Stress Management 7(5), 1177-1180

Perumal, P., 2017. Biochemical Attributes of Mithun Semen. International Journal of Bio - Resource and Stress Management 8(6), 796-801.

Perumal, P., Savino, N., Sangma, C.T.R., Chang, S., Sangtam, T.Z.T., Khan, M.H., Singh, G., Brijesh Kumar, Yadav, D., Srivastava, N., 2017a. Effect of season and age on scrotal circumference, testicular parameters and endocrinological profiles in mithun bulls. Theriogenology 98, 23-29.

Perumal, P., Savino, N., Sangma, C.T.R., Khan, M.H., Ezung, E., Chang, S., Sangtam, T.Z.T., 2017b. Seasonal effect on physiological, reproductive and fertility profiles in breeding mithun bulls. Asian Pacific Journal of Reproduction 6(6), 268-278.

Perumal, P., 2018a. Effect of foot and mouth disease vaccination on seminal antioxidant profiles of mithun. Asian Pacific Journal of Reproduction 7(4), 178-184.

Perumal, P., 2018b. Effect of scrotal insulation on semen quality profiles in mithun. International Journal of BioResource and Stress Management 9(6), 723-728.

Pickett, B.W., Faulkner, L.C., Voss, J.L., 1975. Effect of season on some characteristics of stallion semen. Journal of Reproduction and Fertility 23, 25-28.

Pieri, C., Marra, M., Moroni, F., Recchioni, R., Marcheselli, F., 1994. Melatonin: A peroxyl radical scavenger more effective than vitamin E. Life Science 55(15), 271-276.

Rajoriya, J.S., Kumar, S., Shinde, S., Kumar, A., Perumal, P., Chauhan, M., 2016. Effect of winter and summer season on lipid peroxidation and total seminal plasma protein of Tharparkar bull semen. International Journal of BioResource and Stress Management 7(6), 1356-1360.

Rajoriya, J.S., Prasad, J.K., Ghosh, S.K., Perumal, P., Kumar, A., Kaushal, S., Singh, M., 2013. Effects of seasons on enzymatic changes and cholesterol efflux in relation to freezability in Tharparkar bull semen. Asian Pacific Journal of Reproduction 2(4), 280-288.

Reiter, R.J., 1991. Pineal melatonin: Cell biology of its synthesis and of its physiological interactions. Endocrine Reviews 12(2), 151-180.
Reiter, R.J., Tan, D.X., Kim, S.J., Qi, W., 1998. Melatonin as a pharmacological agent against damage to lipids and DNA. Proceedings of Western Pharmacology Society 41, 229-236.

Saeed, S., Khan, F.A., Rehman, S.B., Khan, D.A., Ahmad, M., 1994. Biochemical parameters in evaluation of oligospermia. Journal of Pakistan Medical Association 44, 137-140.

Sagdeo, L.R., Chitins, A.B., Deshmukh, S.N., Kaikini, A.S., 1991. Seasonal variations in relation to freezability of semen of Jersey and crossbred bulls with varying level of exotic inheritance. Indian Journal of Animal Reproduction 12(2), 117-121.

Salisbury, G.W., VanDemark, N.L., Lodge, J.R., 1985. Physiology of reproduction and artificial insemination of cattle. $2^{\text {nd }}$ ed. W.H. Freeman and Company, 268-274.

Sarkar, M., Dutta Borah, B.K., Bandopadhayay, S., Meyer, H.H.D., Prakash, B.S., 2009. Season of the year influences semen output and concentrations of testosterone in circulation of yaks (Poephagus grunniens L.). Animal Reproduction Science 115, 300-305.

Sivaramalingam, K., 1994. Studies on hypo-osmotic swelling test (HOST) for evaluation of bull spermatozoa. MVSc Thesis, Madras Veterinary College, Madras. India.

Snedecor, S.W., Cochran, W.G., 1994. Statistical methods, $8^{\text {th }}$ edn. University Press, Ames, IA.

Sonmez, M., Yuce, A., Turk, G., 2007. The protective effects of melatonin and Vitamin $E$ on antioxidant enzyme activities and epididymal sperm characteristics of homocysteine treated male rats. Reproductive Toxicology 23(2), 226-231.

Succu, S., Berlinguer, F., Pasciu, V., Satta, V., Leoni, G.G., Naitana, S., 2011. Melatonin protects ram spermatozoa from cryopreservation injuries in a dose-dependent manner. Journal of Pineal Research 50(3), 310-318.

Sullivan, J.J., 1978. Morphology and motility of spermatozoa. In: Physiology of reproduction and artificial insemination of cattle. (Salisbury, G.W., Van Demark, N.L., Lodge, J.R., eds.), $2^{\text {nd }}$ edn. San Francisco, W.H. Free man, 286-328.

Tomar, N.S., 1997. Artificial Insemination and Reproduction of Cattle and Buffalos. Sarojprakashan, Allahabad, India.

Tomas-Zapico, C., Coto-Montes, A., 2005. A proposed mechanism to explain the stimulatory effect of melatonin on antioxidative enzymes. Journal of Pineal Research 39(2), 99-104.

Tramer, F., Rocco, F., Micali, F., Sandri, G., Panfili, E., 1998. Antioxidant systems in rat epididymal spermatozoa. Biology of Reproduction 59, 753-758.

Watson, P.F., 1975. Use of Giemsa Stain to detect change in acrosome of frozen ram spermatozoa. Veterinary Record 97(1), 12-15.

Zarazaga, L.A., Guzman, J.L., Dominguez, C., Perez, M.C., Prieto, R., 2009. Effects of season and feeding level on reproductive activity and semen quality in Payoya buck goats. Theriogenology 71, 1316-1325. 